\title{
Adrenal Suppression and Exogenous Cushing Syndrome After Inhaled and Topical Corticosteroids - Two Clinical Cases and Review of the Subject
}

Gheorghe Serpoi', Constantin Cucu

\begin{abstract}
The undesirable endocrine effects associated with pharmacological therapy with corticosteroids administered orally or parenterally are well-known in medical practice. However, the degree of vigilance is lower when compartmental corticosteroids are used, and it is a widely held assumption that local glucocorticoids rarely produce adrenal insufficiency or exogenous Cushing syndrome. The two cases that we present here demonstrate the appearance of major adrenal suppression and Cushing exogenous syndrome after inadequate use of topical corticosteroids and, the combination of inhaled corticosteroids with nasal glucocorticoids, respectively. The following mini-review shows, from the endocrinologist point of view, the main aspects to be considered by practitioners who recommend local glucocorticoid treatments - i.e. inhaled, topical (cutaneous, oral, nasal, ophthalmic) or intraarticular - to prevent the occurrence of major endocrine syndromes that are met after corticosteroid therapy, tertiary adrenal insufficiency and exogenous Cushing syndrome.
\end{abstract}

Keywords: corticosteroid administration; adrenal suppression; exogenous Cushing

\section{Rezumat}

Efectele endocrine nedorite asociate terapiei farmacologice cu corticosteroizi administrați oral sau parenteral sunt bine cunoscute în practica medicală. Gradul de vigiliență este, însă, mai redus atunci când se folosesc corticosteroizi administrați compartimental, față de care părerea generală este că ar produce arareori insuficiență adrenală sau sindrom Cushing exogen. Cele douza cazuri pe care le prezentăm demonstrează apariția de supresie adrenală importantă și de sindrom Cushing exogen după folosirea inadecvată a dermatocorticoizilor și, respectiv, a combinației de corticosteroizi inhalatori cu glucocorticoizi nazali. Mini-sinteza care urmează prezintă, din perspectiva endocrinologului, principalele aspecte care ar trebui să fie avute în vedere de către practicienii care recomandă tratamente cu glucocorticoizi administrați local - inhalator, topic (cutanat, oral, nazal, oftalmic) sau intra-articular - pentru a preveni apariția sindroamelor endocrine majore generate de corticoterapie: insuficiența adrenală terțiară și sindromul Cushing exogen.

Cuvinte-cheie: corticoterapie; supresie adrenală; Cushing exogen

\footnotetext{
' Department of Endocrinology, CF2 Clinical Hospital Bucharest, Romania

2 "Carol Davila" University of Medicine and Pharmacy, Bucharest, Romania

3 "C.I. Parhon" National Institute of Endocrinology, Bucharest, Romania
}

Corresponding author.

Gheorghe Serpoi, Clinical Department of Endocrinology, CF2 Hospital, 63-65 Marasti Avenue, Bucharest, Romania. E-mail: gserpoi@gmail.com 


\section{INTRODUCTION}

Corticosteroid (CS) therapy is used by $1 \%$ of world population, especially for non-endocrinological indications. Compartmental administration of CS (i.e. topical, inhaled or intraarticular) was developed to prevent undesired effects. Still even these therapies could generate major endocrine syndromes, as our two cases tend to illustrate - Table 1 and Table 2.

\section{Table 1. Case no. 1 description}

\begin{tabular}{|c|c|c|c|c|}
\hline $\begin{array}{l}\text { TC, male, born in } \\
\text { rheumatologist } \\
\text { Patient, a trained } \\
\text { exposed the last } \\
\text { therapy - daily a } \\
\text { pping") with a hi } \\
\text { onate cream } 0.0 \\
\text { clobetasol/day. }\end{array}$ & $\begin{array}{l}960 \text {, was e } \\
\text { er radiolog } \\
\text { thlete, with } \\
\text { vo years to } \\
\text { lications a } \\
\text { ly potent t } \\
\text { using an }\end{array}$ & $\begin{array}{l}\text { valuated in M } \\
\text { ical evidences } \\
\text { psoriasis fror } \\
\text { intense local } \\
\text { and weekly occ } \\
\text { opical agent, c } \\
\text { average of } 20\end{array}$ & $\begin{array}{l}\text { y } 2016 \text {, refer } \\
\text { of vertebral } \\
\text { the age of } \\
\text { lucocorticol } \\
\text { lusive therap } \\
\text { ass I, clobet } \\
\text {-225 g/weel }\end{array}$ & $\begin{array}{l}\text { ed by } \\
\text { ushes. } \\
5 \text { was } \\
\text { (GC) } \\
\text { ("wra- } \\
\text { sol-propi- } \\
\text { i.e. 14mg }\end{array}$ \\
\hline $\begin{array}{l}\text { 2016, May. Clinic } \\
\text { mass index=38. } \\
\text { re = 140/95 mm } \\
\text { and muscular } \\
\text { with widespread } \\
\text { vel, antero-axilla } \\
\text { ecchymosis of v } \\
\text { lesions on elbow } \\
\text { men; varicosities } \\
\text { venous ulcer on }\end{array}$ & $\begin{array}{l}\text { I Exam: He } \\
\text { Kg/m2; hea } \\
\text { g; plethoric } \\
\text { ting at the } \\
\text { xfoliation a } \\
\text { striae and } \\
\text { ious ages } \\
\text { knees, leg } \\
\text { t the lower } \\
\text { e external }\end{array}$ & $\begin{array}{l}\text { ght }=179 \mathrm{~cm} ; \\
\text { irt rate= } 68 / \mathrm{mir} \\
\text { facies; Cushir } \\
\text { level of proxim } \\
\text { nd areas of at } \\
\text { n the flanks; } f \\
\text { on the arms ar } \\
\text { s and the ante } \\
\text { members, wit } \\
\text { part of the righ }\end{array}$ & $\begin{array}{l}\text { Jeight=124K } \\
\text {, regular; blo } \\
\text { goid fat redis } \\
\text { al groups; th } \\
\text { ophy at abd } \\
\text { cial telangie } \\
\text { d forearms; } \\
\text { ior wall of th } \\
\text { stasis dern } \\
\text { t leg. }\end{array}$ & $\begin{array}{l}\text { Body- } \\
\text { d pressu- } \\
\text { ribution } \\
\text { skin, } \\
\text { ninal le- } \\
\text { tasia and } \\
\text { soriatic } \\
\text { abdo- } \\
\text { atitis and }\end{array}$ \\
\hline $\begin{array}{l}\text { Hormonal } \\
\text { testing } \\
\text { (blood, 8AM) }\end{array}$ & $\begin{array}{c}\text { May } \\
2016^{\star} \\
1^{\text {st }} \text { visit }\end{array}$ & $\begin{array}{l}\text { August } \\
2016^{\star *} \\
2^{\text {nd }} \text { visit } \\
\end{array}$ & $\begin{array}{l}\text { August } \\
2017^{* *} \\
3^{\text {rd }} \text { visit }\end{array}$ & $\begin{array}{c}\text { Feb } \\
2018^{* \star} \\
4^{\text {th }} \text { visit }\end{array}$ \\
\hline $\begin{array}{l}\text { Cortisol } \\
\text { range: 101-535 } \\
\text { nmol/L } \\
(3.7-19.4 \mathrm{ug} / \mathrm{dl})\end{array}$ & $\begin{array}{c}\mathbf{4 . 8 3} \\
\mathbf{n m o l} / \mathrm{L} \\
(0.17 \mathrm{ug} / \\
\mathrm{dl})\end{array}$ & $\begin{array}{c}\mathbf{2 7 . 5 9} \\
\mathbf{n m o l} / \mathbf{L} \\
(1.0 \mathrm{ug} / \mathrm{dl})\end{array}$ & $\begin{array}{c}19.31 \\
\mathbf{n m o l} / \mathbf{L} \\
(0.7 \mathrm{ug} / \mathrm{dl})\end{array}$ & $\begin{array}{c}\mathbf{6 8 . 9 7} \\
\mathbf{n m o l} / \mathrm{L} \\
(2.5 \mathrm{ug} / \\
\mathrm{dL})\end{array}$ \\
\hline $\begin{array}{l}\text { ACTH } \\
\text { range: 5-46pg/ } \\
\text { ml }\end{array}$ & $\begin{array}{c}2.43 \mathrm{pg} / \\
\mathrm{ml}\end{array}$ & $7.47 \mathrm{pg} / \mathrm{ml}$ & $4.5 \mathrm{pg} / \mathrm{ml}$ & $\begin{array}{c}8.65 \mathrm{pg} / \\
\mathrm{mL}\end{array}$ \\
\hline $\begin{array}{l}\text { "Profound suppressio } \\
\text { non-glucocorticoster } \\
\text { "' Suppression of HPA }\end{array}$ & $4,14,20$ mont & h following cessat & on of clobetasol & $\begin{array}{l}\text { ent received } \\
\text { py begun. } \\
\text { erapy. }\end{array}$ \\
\hline $\begin{array}{l}\text { Severe exogenol } \\
\text { - Severe osteop } \\
\text { brae, MRI dem } \\
\text { (1) Grade } 3 \text { fract } \\
\text { resulting in narro } \\
\text { the spinal cord; } \\
\text { compression at } \\
\text { compression at } \\
\text { to Genant metho } \\
\text { - Diabetes mell } \\
\text { - Sub-capsular } \\
\text { cement. }\end{array}$ & $\begin{array}{l}\text { Cushing } \mathrm{S} \\
\text { rosis, with } \\
\text { nstrated: } \\
\text { e with com } \\
\text { ving of the } \\
\text { Grade } 2 \mathrm{fr} \\
\text { and L3; ( } 3 \\
5, T 7 \text { and } \mathrm{T} \\
\text { of assessr } \\
\text { us and obe } \\
\text { ataract - } \mathrm{t}\end{array}$ & $\begin{array}{l}\text { yndrome with } \\
\text { crushes of the } \\
\text { pression of th } \\
\text { vertebral cana } \\
\text { actures with a } \\
\text { ) Grade } 2 \text { frac } \\
\text { 8; diffuse dem } \\
\text { nent). } \\
\text { sity. } \\
\text { eated with bil }\end{array}$ & $\begin{array}{l}\text { he following } \\
\text { thoracolum } \\
\text { T12 verteb } \\
\text { and contact } \\
\text { terior and s } \\
\text { ures with an } \\
\text { neralization } \\
\text { teral crystal }\end{array}$ & $\begin{array}{l}\text { ar verte- } \\
\text { al body, } \\
\text { vith } \\
\text { perior } \\
\text { erior } \\
\text { according } \\
\text { ne repla- }\end{array}$ \\
\hline
\end{tabular}

SIDEBAR. The possibility of exogenous Cushing syndrome after treatments with topical corticosteroids was also emphasized in earlier syntheses. In an article from 2012 are depicted 5 cases of Cushing syndrome occurring after clobetasol-propionate topical treatments ${ }^{1}$. The patient presented by us stands out by the severity of clobetasol-induced osteoporosis, suggesting a persistent and long-lasting exposure at high doses.

$\mathrm{ACTH}=$ corticotropin; HPA = hypothalamic-pituitary-adrenal.

Table 2. Case no. 2 description

MA, male, born in 1960, was evaluated in August 2015, referred by infectious disease specialist after a prolonged episode of severe cholangitis, with sepsis, resulting in 2 months (June-July 2015) anti-infectious and pharmacological GC therapy. Patient noticed in the period July - August 2015 low values of blood pressure (90/60 mmHg, significantly lower than his usual 130-140/85-90 $\mathrm{mmHg}$ ). The patient is known from 2008 with asthma, managed with various forms of ICS - initially, budesonide for roughly 2 years, then with a stronger ICS, fluticasone propionate for 3 years. After October 2013 patient developed clinical signs suggestive of Cushing syndrome: plethora, purple striae on the abdomen and flanks, thinning of the skin with bruising, ecchymosis, centripetal fat redistribution and muscle wasting; diabetes mellitus (glycaemia between 150-200 mg/dL) was demonstrated. ICS were discontinued; prolonged action beta-2 agonist [indacaterol] started. 2015 August - Long Synacthen Stimulation Test [Synacthen-depot $1 \mathrm{mg}$, intramuscular] - at $6 \mathrm{~h}-$ Cortisol $=1023.5 \mathrm{nmol} / \mathrm{L}$ (37.1 ug/ $\mathrm{dL})$; at $24 \mathrm{~h}$ - Cortisol $=902 \mathrm{nmol} / \mathrm{L}(32.7 \mathrm{ug} / \mathrm{dL})$; normal response definition: Cortisol = $>550 \mathrm{nmol} / \mathrm{L}(>19.9 \mathrm{ug} / \mathrm{dL})$.

\begin{tabular}{|c|c|c|c|c|c|}
\hline $\begin{array}{l}\text { Hormonal } \\
\text { testing } \\
\text { (blood, 8AM) }\end{array}$ & $\begin{array}{l}\text { August } \\
2013^{a}\end{array}$ & $\begin{array}{l}7^{\text {st }} \text { visit } \\
- \text { Aug } \\
2015^{b}\end{array}$ & $\begin{array}{l}2^{\text {nd }} \text { visit } \\
\text { - Feb } \\
2017^{c}\end{array}$ & $\begin{array}{l}3^{\text {rd }} \text { visit } \\
- \text { May } \\
2017^{d}\end{array}$ & $\begin{array}{l}4^{\text {th }} \text { visit } \\
- \text { Nov } \\
2017^{e}\end{array}$ \\
\hline $\begin{array}{l}\text { Cortisol - } \\
\text { range: 101- } \\
535 \mathrm{nmol} / \mathrm{L} \\
(3.7-19.4 \\
\mathrm{ug} / \mathrm{dl})\end{array}$ & $\begin{array}{c}\mathbf{2 5 . 1} \\
\mathrm{nmol} / \mathrm{L} \\
(0.9 \mathrm{ug} / \\
\mathrm{dl})\end{array}$ & $\begin{array}{c}\mathbf{2 8 7} \\
\mathrm{nmol} / \mathrm{L} \\
(10.4 \mathrm{ug} / \\
\mathrm{dl})\end{array}$ & $\begin{array}{c}\mathbf{2 6 . 9} \\
\mathrm{nmol} / \mathrm{L} \\
(0.97 \mathrm{ug} / \\
\mathrm{dl})\end{array}$ & $\begin{array}{c}\mathbf{7 0 . 7} \\
\mathbf{n m o l} / \mathbf{L} \\
(2.56 \mathrm{ug} / \\
\mathrm{dl})\end{array}$ & $\begin{array}{c}\mathbf{1 8 0 . 8} \\
\mathbf{n m o l} / \mathrm{L} \\
(6.55 \\
\mathrm{ug} / \mathrm{dL})\end{array}$ \\
\hline $\begin{array}{l}\text { ACTH } \\
\text { range: 5-46 } \\
\mathrm{pg} / \mathrm{ml}\end{array}$ & $\begin{array}{c}5.48 \\
\mathrm{pg} / \mathrm{ml}\end{array}$ & $\begin{array}{c}31.6 \mathrm{pg} / \\
\mathrm{ml}\end{array}$ & $\begin{array}{c}<1 \mathrm{pg} / \\
\mathrm{ml}\end{array}$ & $\begin{array}{c}9.98 \mathrm{pg} / \\
\mathrm{ml}\end{array}$ & $\begin{array}{c}28.7 \\
\mathrm{pg} / \mathrm{mL}\end{array}$ \\
\hline $\begin{array}{l}\text { DHEA-S } \\
\text { range: 49-362 } \\
\mathrm{pg} / \mathrm{ml}\end{array}$ & - & $\begin{array}{c}27.5 \mathrm{ug} / \\
\mathrm{dl}\end{array}$ & $\begin{array}{l}20.3 \\
\mathrm{ug} / \mathrm{dl}\end{array}$ & - & $\begin{array}{c}26.4 \\
\mu \mathrm{g} / \mathrm{dL}\end{array}$ \\
\hline $\begin{array}{l}\text { Androstene- } \\
\text { dione range: } \\
0.64-2.97 \\
\mathrm{pg} / \mathrm{ml}\end{array}$ & - & $\begin{array}{c}0.62 \mathrm{ng} / \\
\mathrm{ml}\end{array}$ & - & - & - \\
\hline $\begin{array}{l}\text { Renin } \\
\text { range: } 4.4- \\
46.1 \mathrm{pg} / \mathrm{ml}\end{array}$ & - & $14 \mathrm{uU} / \mathrm{ml}$ & -- & - & - \\
\hline
\end{tabular}




\begin{tabular}{|c|}
\hline $\begin{array}{l}\text { Two years before referral - tests suggestive of adrenal suppres- } \\
\text { sion preceding the assumed adrenal crisis during the sepsis. } \\
{ }^{b} \text { One month after presumed adrenal crisis. Tests indicate a normal } \\
\text { cortisol response (i.e. }>20 \text { ug/dL } 24 \mathrm{~h} \text { after Synacthen), but a low } \\
\text { level of adrenal androgens (AA). Low AA suggests relative } \mathrm{Al}^{2} \text {. } \\
\text { Dissociation between GC and AA might be generated by sepsis }{ }^{3} \text {. } \\
\text { c In February } 2017 \text { clinical exam revealed findings suggesting of } \\
\text { recurrent exogenous Cushing syndrome: muscular wasting, weight } \\
\text { gain with fat redistribution, facial plethora, persistently high BP } \\
\text { values, and high self-monitoring glycaemia (170- } 250 \text { mg/dL). We } \\
\text { found out about the use of nasal betamethasone with an intensifi- } \\
\text { cation of self-administration suggesting overtreatment in the last } \\
6 \text { months. Betamethasone stopped. } \\
\text { d HPA function was still subnormal, with low cortisol and ina- } \\
\text { dequately normal ACTH - tertiary hypoadrenalism. GC replace- } \\
\text { ment therapy begun - prednisone } 5 \text { mg/day. } \\
\text { In November } 2017,9 \text { months after nasal betamethasone was } \\
\text { stopped, HPA axis function was still impaired; the control of dia- } \\
\text { betes was improved - Glycaemia= } 105 \text { mg/dL, HbA1c = } 6.1 \% \text {. The } \\
\text { GC replacement therapy was gradually suspended, maintaining CS } \\
\text { supplementation in stress and re-test HPA-axis after } 3 \text { months. }\end{array}$ \\
\hline $\begin{array}{l}\text { SIDEBAR. A case of Cushing syndrome following ICS, as we } \\
\text { presented here, was reported in } 2013 \text {, where concomitant use of } \\
\text { intranasal GC played an important role, too }{ }^{4} \text {. }\end{array}$ \\
\hline \\
\hline
\end{tabular}

\section{LOCAL (COMPARTMENTAL) GLUCOCORTICOID ADMINISTRATION - ENDOCRINOLOGIST MINI-REVIEW}

According to the pharmaceutical route of administration glucocorticoid (GC) therapy can be divided in: (a) systemic: oral, intravenous, intramuscular, and subcutaneous; (b) local or compartmental: topic (cutaneous, nasal, ophthalmic); inhaled; intraarticular. The therapeutic index for GC depends on the systemic absorption of the drug, the metabolism (renal and/or hepatic clearance) and the degree of plasma protein binding.

Topical GC are used for a large spectrum of dermatological conditions and show a great variability in terms of bioavailability and pharmacokinetics (e.g. the fluorinated compounds, dexamethasone, triamcinolone, betamethasone, and beclomethasone are better absorbed through skin than the unfluorinated agents like hydrocortisone). Topical GC can be classified according to their potency and the capacity to inhibit HPA axis - Table 3 [based on World Health Organization (WHO) classification]. As a rule, higher dermatological potency will result in higher degree of HPA axis suppression and risk for adrenal insufficiency (AI). Super-active agents such as clobetasol ointment 0.05\% can produce HPA suppression at doses as low as $2 \mathrm{~g} /$ day and can result in Cushing syndrome at doses larger than $50 \mathrm{~g} /$ week (our patient in case no. 1 using $200 \mathrm{~g} /$ week). Pharmacological estimation showed that daily topical use of $20 \mathrm{mg}$ clobetasol (= $40 \mathrm{~g}$ ointment clobetasol-propionate $0.05 \%$ ) have the same systemic effect as the daily oral dose of $60 \mathrm{mg}$ prednisone. Accordingly, therapy with clobetasol should not exceed $50 \mathrm{~g} /$ week, no longer than 2 weeks on a row.

Children showed a greater sensibility with HPA suppression demonstrated at doses of $14 \mathrm{~g} /$ week clobetasol-propionate or $49 \mathrm{~g} /$ week betamethasone-dipropionate $^{5}$. There are reported an increasingly number of cases with HPA axis severely suppressed. In our patient (case no. 1), AI persisted even after 20 months since clobetasol suspension.

Inhaled corticosteroids (ICS), are pivotal to achieve asthma control in both children and adults. In $\mathrm{Ta}-$

Table 3. Topical synthetic GC potency and capacity to inhibit HPA axis

\begin{tabular}{|c|c|c|c|}
\hline Class & Dermatological potency & HPA-suppression & Examples \\
\hline \multirow{3}{*}{$\begin{array}{l}\text { Class I } \\
\text { [WHO - Ultra High] }\end{array}$} & \multirow{3}{*}{$\begin{array}{l}\text { SUPER ACTIVE } \\
\text { (SUPER POTENT) }\end{array}$} & \multirow{6}{*}{+++++} & Clobetasol-propionate cream $0.05 \%$ \\
\hline & & & Diflorasone diacetate ointment, $0.05 \%$ \\
\hline & & & Betamethasone-dipropionate-glycol 0.05\% \\
\hline \multirow{3}{*}{$\begin{array}{l}\text { Class } \\
\text { II-III } \\
\text { [WHO - High] }\end{array}$} & \multirow{3}{*}{ HIGH POTENCY } & & Betamethasone-dipropionate ointment 0.05\% \\
\hline & & & Fluocinonide cream, ointment or gel, 0.05\% \\
\hline & & & Triamcinolone acetonide ointment $0.5 \%$ \\
\hline \multirow{4}{*}{$\begin{array}{l}\text { Class } \\
\text { IV-V } \\
\text { [WHO -Moderate] }\end{array}$} & \multirow{4}{*}{ MEDIUM STRENGTH } & \multirow{4}{*}{+++} & Betamethasone-valerate cream $0.1 \%$ \\
\hline & & & Fluocinolone acetonide cream $0.025 \%$ \\
\hline & & & Triamcinolone acetonide lotion $0.1 \%$ \\
\hline & & & Hydrocortisone 17 -valerate cream $0.2 \%$ \\
\hline \multirow{5}{*}{$\begin{array}{l}\text { Class } \\
\text { VI-VII } \\
{[\mathrm{WHO}-\text { Low }]}\end{array}$} & \multirow{5}{*}{ LOW POTENCY } & \multirow{5}{*}{++} & Betamethasone-valerate cream 0.05\% \\
\hline & & & Fluocinolone acetonide solution $0.01 \%$ \\
\hline & & & Betamethasone valerate lotion 0.05\% \\
\hline & & & Methylprednisolone acetate cream $0.25 \%$ \\
\hline & & & Hydrocortisone acetate cream $0.5 \% 1.0 \%$ \\
\hline
\end{tabular}


Table 4. Classification of ICS according with HPA suppression ${ }^{6,7}$

\begin{tabular}{|c|c|c|c|c|c|c|}
\hline \multirow{2}{*}{ ICS } & \multirow{2}{*}{$\begin{array}{l}\text { Asthma } \\
\text { potency }\end{array}$} & \multirow{2}{*}{$\begin{array}{c}\text { HPA- } \\
\text { suppression }\end{array}$} & \multirow{2}{*}{$\begin{array}{c}\text { Daily dose [ug] } \\
\text { suppressing } \\
\text { cortisol } 20 \%^{*}\end{array}$} & \multicolumn{3}{|c|}{ Equivalent dose (ug/day) } \\
\hline & & & & low & medium & large \\
\hline $\begin{array}{l}\text { Fluticasone - } \\
\text { propionate }\end{array}$ & +++++ & \multirow{5}{*}{$\begin{array}{c}++++ \\
+++ \\
++ \\
-\end{array}$} & 900 & $100-250$ & $250-500$ & $>500$ \\
\hline $\begin{array}{l}\text { Mometasone - } \\
\text { furoate }\end{array}$ & ++++ & & 660 & 200 & $200-400$ & $>400$ \\
\hline $\begin{array}{l}\text { Beclomethasone - } \\
\text { dipropionate }\end{array}$ & ++ & & 500 & $100-200$ & $200-400$ & $>400$ \\
\hline Budesonide & + & & 600 & $200-400$ & $400-800$ & $>800$ \\
\hline Ciclesonide & +++ & & 1200 & $80-160$ & $160-320$ & $>320$ \\
\hline
\end{tabular}

ble 4 ICS are sorted according with potency and HPA suppression. One ICS with higher potency needs lower inhaled daily dose for equivalent efficacy.

The schematic pharmacokinetic of ICS: (a) - 60$90 \%$ of the inhaled drug remains in pharynx and it is swallowed; from gut, it is absorbed and inactivated in liver at the first-pass by enzymes linked with CYP3A ${ }^{2}$. Inhibitors for CYP3A cytochrome increase the GC levels and amplifies systemic effects (moderate inhibitors, e.g. diltiazem; tibolone; dronedarone; amiodarone; mifepristone; erythromycin; fluconazole; grapefruit juice, and strong inhibitors, e.g., ceritinib; indinavir; clarithromycin; itraconazole; ketoconazole). Ciclesonide, fluticasone and mometasone are virtually completely metabolized, while $11 \%$ budesonide and 20-40\% beclomethasone escapes the first-pass and reach the systemic circulation. Therefore, it is better to select one ICS with greater hepatic clearance. (b) - 10-40\% of the inhaled drug reach the respiratory system and then delivered into circulation (e.g. $20 \%$ of inhaled fluticasone).

In terms of prednisolone equivalency, adrenal suppression with a large dose of budesonide (1000 ug per day) was estimated to be as high as with $8.7 \mathrm{mg}$ of prednisolone ${ }^{8}$. Important dose-effect relationship between ICS and urinary cortisol suppression was documented with beclomethasone (8.4\% per $100 \mu \mathrm{g} ; \mathrm{p}=0.029)$, followed by fluticasone (3.2\% per $100 \mu \mathrm{g} ; \mathrm{p}<0.001)$, and budesonide (3.1\% per $100 \mu \mathrm{g} ; \mathrm{p}=0.001)$; no significant suppression was associated with ciclesonide'. Pharmacological properties of ciclesonide made it the safest ICS [i.e. - 160-600 ug/day ciclesonide didn't affect cortisol level $]^{10}$. The highest risk for adrenal suppression is encountered in children, especially when ICS was fluticasone ${ }^{11}$, if the ICS were used for more than
6 months and if were associated with hypoglycemia, mental impairment, fatigability, anorexia, Cushingoid appearance or impaired linear growth.

\section{ENDOCRINE EFFECTS OF COMPARTMENTAL GC ADMINISTRATION}

The undesired side effects after compartmental GC administration could be local, specific to type of therapy and systemic, common to all types. The endocrine systemic effects are: (1) HPA axis suppression; (2) exogenous Cushing syndrome.

\section{(1) HPA axis suppression and adrenal insufficiency}

GC therapy is the most common cause of adrenal insufficiency (AI). GC administration decrease hypothalamic corticoliberin (CRH), as well as pituitary adreno-corticotropic hormone $(\mathrm{ACTH})$ production and induce adrenocortical cells functional inhibition and atrophy. GC use in a dose larger than the equivalent of $20 \mathrm{mg}$ prednisone/day for more than 3 weeks can induce HPA-axis suppression. When are taken at the bed-time even doses of $\geq 5 \mathrm{mg}$ prednisone/day can induce suppression ${ }^{12}$. Adrenal suppression was documented both after oral GC and after ICS ${ }^{13}$. In a study of HPA function after systemic GC use in 3166 patients, the median prevalence of AI was $37 \%$ and the recovery of the normal function occurred in $58.8 \%$ patients 1-2 years after systemic $G C$ withdrawal ${ }^{14}$. In a recent study with 404 patients taking oral, topical, intranasal or inhaled GC therapy, 33.2\% had a subnormal short Synacthen stimulation test (SST) response ${ }^{15}$. In a meta-analysis conducted on 3753 subjects exposed to 
Adrenal Suppression and Exogenous Cushing Syndrome After Inhaled and Topical Corticosteroids

\begin{tabular}{|c|c|c|}
\hline & HPA axis suppression risk & Prevention \\
\hline \multicolumn{3}{|c|}{ COMMON FACTORS } \\
\hline General aspect & $\begin{array}{l}\text { Cushingoid features } \rightarrow \text { HPA axis suppression is } \\
\text { very likely }\end{array}$ & $\begin{array}{l}\text { Absence of Cushingoid features } \rightarrow \text { HPA suppression } \\
\text { is unlikely }\end{array}$ \\
\hline Daily dose & Best way to predict HPA suppression & Use of minimal doses \\
\hline Route of administration & $\begin{array}{l}\text { Continuous use increases the risk } \\
\square \text { Several daily administrations increase risk }\end{array}$ & $\begin{array}{l}\text { DIf possible - pulsatile or alternant therapy } \\
\text { U Unique administration, in the morning }\end{array}$ \\
\hline Duration and cumulative dose & Weak determinants of the risk & No suppression for shorter periods than 2 weeks \\
\hline \multicolumn{3}{|c|}{ SPECIFIC FACTORS FOR INHALED CORTICOSTEROIDS } \\
\hline Duration & $>6$ month, with high doses & \multirow{3}{*}{$\begin{array}{l}\text { O Minimal effective dose } \\
\text { O Optimization of compliance } \\
\text { O Mouth and pharynx washing } \\
\text { O Association of other bronchodilator agents } \\
\text { O Non-pharmacological methods (vaccinations, avoi- } \\
\text { dance of allergens) }\end{array}$} \\
\hline Combined administration & $\begin{array}{l}\text { Concomitant use of other kinds of GC } \\
\text { (e.g. systemic GC in asthma exacerbation or } \\
\text { nasal for rhinitis) }\end{array}$ & \\
\hline Low weight patients & $\begin{array}{l}\text { Body mass index }<15 \text { percentile for age } \\
\text { Children and teenagers }\end{array}$ & \\
\hline \multicolumn{3}{|c|}{ SPECIFIC FACTORS FOR TOPICAL GC } \\
\hline $\begin{array}{l}\text { High doses of active and super } \\
\text { active derivate }\end{array}$ & $\begin{array}{l}\text { With class I (clobetasol) adrenal suppression } \\
\text { can occur in } 3 \text { weeks. } \\
\text { Ointment has higher risk than any other phar- } \\
\text { maceutical form }\end{array}$ & \multirow{2}{*}{$\begin{array}{l}\text { Lowest possible dosage } \\
\square \text { Decrease doses in children }(1 / 5 ; 2 / 5 ; 1 / 3 \text { - of the } \\
\text { dose required to adults in todlers, children and } \\
\text { teenagers, respectively) } \\
\text { Avoidance of areas with high absorption rate (face, } \\
\text { genitals) or deteriorated skin }\end{array}$} \\
\hline The application surface & $\begin{array}{l}\text { D Large areas } \\
\text { Regions with high permeability } \\
\text { Occlusive therapy (increases potency by } 100 \\
\text { times) } \\
\square \text { Children, old people, hepatic failure }\end{array}$ & \\
\hline
\end{tabular}

systemic or local GC, the percentages of tertiary $\mathrm{AI}$ were: $48.3 \%$ - after systemic GC; $6.8 \%$ - after ICS; $4.7 \%$ - after topical corticosteroids; $4.2 \%$ - after intranasal GC; $52.2 \%$ - after intraarticular $\mathrm{GC}^{16}$. The combined GC therapy (i.e. ICS and intranasal GC) resulted in a higher risk of HPA suppression (e.g. an 19\% excess). In a recent article, $61 \%$ of patients with adrenal suppression after systemic GC had normal SST after 2 years ${ }^{17}$. In this study, age, gender, body mass index, indications for GC use, and basal corticotropin levels were not predictive of HPA axis recovery; one useful finding was that early morning cortisol of $8.8 \mu \mathrm{g} / \mathrm{dL}$ predicted a positive SST response.

Specific factors for prediction of HPA suppression after local GC are in Table 5.

The basic principle for the GC withdrawal is to avoid sudden discontinuation. Instead, the daily dose gradually decreases with $2.5 \mathrm{mg}$ prednisone/day every 3-4 days, until are reached physiological doses (= equivalent of 5-7.5 mg prednisone/day). Estimations are based on physiological cortisol production $5.7-7.4 \mathrm{mg} / \mathrm{m}^{2} /$ day, corresponding to a daily dose of $10-15 \mathrm{mg}$ hydrocortisone $/ \mathrm{m}^{2} /$ day, orally or $6-8 \mathrm{mg} / \mathrm{m}^{2} /$ day, intravenous, lower than previously thought ${ }^{18}$. After these doses are reached, taper slower, $1 \mathrm{mg}$ prednisone every 2-4 weeks until cessation OR testing with SST and stop the GC whenever the test is normal. Proposed algorithm for HPA assessing for practitioners using GC therapy see Table 6.

Adrenal crisis is a medical emergency. Adrenal crisis in tertiary AI occur after abrupt discontinuation of GC. The frequency of adrenal crisis is higher in tertiary AI, i.e. 15.1 cases in 100 patients/year, than in primary AI, 5.2 cases, or secondary AI, 3.6 cases in 100 patients/year ${ }^{20}$. In Table 7 are presented the updated criteria for diagnosis of adrenal crisis and basic treatment measures.

\section{(2) Exogenous Cushing syndrome}

Exogenous Cushing syndrome is the most common form of Cushing syndrome. The main features and resemblances with endogenous Cushing syndrome are listed in Table 8. In children, first significant undesired effect associated with GC use is diminished linear growth, encountered even with short-term ICS (i.e. 7 days) if high-doses are used ${ }^{22}$.

Glucocorticoid-induced osteoporosis (GIO) is one of most important feature of exogenous Cushing syndrome and the most frequent form of iatrogenic osteoporosis. GC effects on bone result in 2 phases: first 
Gheorghe Serpoi et al.

Table 6. Algorithm for HPA-suppression during local GC administration ${ }^{15,17,19}$

\begin{tabular}{|c|c|}
\hline \multicolumn{2}{|r|}{ Step I - Risk estimation } \\
\hline Who to screen? & $\begin{array}{l}\text { O Cushingoid appearance, OR } \\
\text { O suspected Al: weakness, anorexia, nausea, diarrhea, abdominal pain, morning headaches, myalgia, arthralgia, } \\
\text { hypoglycemia, hypotension, OR } \\
\text { O large ICS doses (i.e. fluticasone or mometasone }>400 \mathrm{ug} / \text { day; budesonide or beclomethasone }>800 \text { ug/day) } \\
\quad \text { - for }>3 \text { weeks in last } 3 \text { months } \\
\text { O large topical corticosteroids doses - clobetasol } 0.05 \%>2 \mathrm{~g} / \text { day or treatment over } 2 \text { weeks with }>100 \mathrm{~g} \text { clobe- } \\
\text { tasol / week, OR } \\
\text { O association with oral GC }>2 \text { weeks continuously or }>3 \text { weeks in last } 6 \text { months, OR } \\
\text { O association with CYP450 3A inhibitors, OR } \\
\text { O yearly for any patient using large doses of compartmental GC }\end{array}$ \\
\hline How to screen? & $\begin{array}{l}\text { Morning 8- 9AM serum cortisol }{ }^{*} \text { - A baseline cortisol result below } 100 \mathrm{nmol} / \mathrm{l} \text { is considered highly indicative of } \\
\text { adrenal insufficiency } \\
\text { Free urinary cortisol - [normal range in children }=5.5-74 \mathrm{nmol} / \mathrm{L}(2-26 \mathrm{ug} / \mathrm{L}) \text {; in adults }=14-152 \mathrm{nmol} / \mathrm{L}(5-55 \\
\mathrm{ug} / \mathrm{L})] \text {. }\end{array}$ \\
\hline \multicolumn{2}{|r|}{ Step II - Normal functioning hypothalamic-pituitary-adrenal (HPA) axis } \\
\hline $\begin{array}{l}\text { Cortisol } \\
>348 \mathrm{nmol} / \mathrm{L}(12.6 \mathrm{ug} / \mathrm{dL})\end{array}$ & $\begin{array}{l}\rightarrow \text { rules out significant suppression of HPA axis; no need for oral substitution therapy or GC supplementation } \\
\text { before major surgery. } \\
\text { If the manifestation of adrenal deficit is persistent } \rightarrow \text { perform SST }\end{array}$ \\
\hline \multicolumn{2}{|r|}{ Step III - Equivocal functioning HPA axis } \\
\hline $\begin{array}{l}\text { Cortisol }= \\
35-348 \mathrm{nmol} / \mathrm{L} \\
(1.26-12.6 \mathrm{ug} / \mathrm{dL})\end{array}$ & $\begin{array}{l}\rightarrow \text { Perform } 250 \text { ug short Synacthen stimulation test }(\mathrm{SST}) \text {. Inadequate = Cortisol <550 nmol/L }(19.8 \mathrm{ug} / \mathrm{dL}) \rightarrow \\
\text { begin oral substitution and GC supplements before major surgery; } \\
\text { reduce doses of compartmental GC; } \\
\text { repeat cortisol testing in } 3 \text { months. }\end{array}$ \\
\hline \multicolumn{2}{|r|}{ Step IV - Suppressed HPA axis } \\
\hline $\begin{array}{l}\text { Cortisol } \\
<35 \mathrm{nmol} / \mathrm{L} \\
(<1.26 \mathrm{ug} / \mathrm{dL})\end{array}$ & $\begin{array}{l}\rightarrow \text { Diagnose adrenal insufficiency - no need to perform SST } \\
\text { start substitution therapy or GC; supplements before major surgery; } \\
\text { reduce doses of compartmental GC; } \\
\text { repeat cortisol testing in } 3 \text { months. } \\
\text { Note! In patients treated with local GC even excessive amounts, resulting in Cushingoid traits might not result in } \\
\text { sufficient serum concentration in stress situations. That's why local GC withdrawal needs the concomitant use } \\
\text { of oral GC with replacement dose and GC supplementation in stressful events. }\end{array}$ \\
\hline & $\begin{array}{l}\text { Romania, and insulin-induced hypoglycemia test (ITT), the gold standard for assessing the HPA axis, is cumbersome to use outside endocrinological } \\
\text { ched validated basal tests for rapid detection and/or referral of adrenal suppression. } \\
\text { al axis; GC = glucocorticoids; } \mathrm{Al}=\text { = adrenal insufficiency; ICS = inhaled corticosteroids; SST = short Synacthen stimulation test. }\end{array}$ \\
\hline
\end{tabular}

Table 7. Definitions, severity and treatment of adrenal crisis ${ }^{21}$

\begin{tabular}{|c|c|}
\hline \multirow[t]{2}{*}{ Definition } & $\begin{array}{l}\text { A) Major impairment of general health with at least two of the following: } \\
\text { 1. Hypotension (systolic blood pressure }<100 \mathrm{mmHg} \text { ) } \\
\text { 2. Nausea or vomiting } \\
\text { 3. Severe fatigue } \\
\text { 4. Fever } \\
\text { 5. Somnolence } \\
\text { 6. Hyponatraemia }(\leq 132 \mathrm{mmol} / \mathrm{l}) \text { or hyperkalaemia } \\
\text { 7. Hypoglycaemia }\end{array}$ \\
\hline & B) Prompt clinical improvement after parenteral hydrocortisone \\
\hline \multirow[t]{4}{*}{ Severity } & Grade 1 - outpatient care only \\
\hline & Grade 2 - hospital care (general ward), no need for intensive care \\
\hline & Grade 3 - admission to intensive care unit \\
\hline & Grade 4 - death from adrenal crisis (with or without GC administration) \\
\hline \multirow{5}{*}{$\begin{array}{l}\text { Treatment } \\
\text { confirmed or } \\
\text { suspected adrenal } \\
\text { crisis [treatment } \\
\text { is started before } \\
\text { biochemical confir- } \\
\text { mation] }\end{array}$} & $\rightarrow$ Establishing an intravenous route \\
\hline & $\rightarrow$ Sampling the blood for glycaemia, $\mathrm{Na}$, K, hemoleucogram, cortisol \\
\hline & $\begin{array}{l}\rightarrow \text { Hydrocortisone: } 100 \mathrm{mg} \text { bolus given immediately followed by } 200 \mathrm{mg} / \text { day as continuous infusion or frequent i.v./ } \\
\text { i.m. boluses }(50 \mathrm{mg} \text { ) every } 6 \mathrm{~h}\end{array}$ \\
\hline & $\begin{array}{l}\rightarrow \text { Intravenous substitution of fluids: } 1000 \mathrm{ml} \text { of } 0.9 \% \text { sodium chloride during the first } 60 \text { min }+ \text { glucose } 5 \% \text { [if } \\
\text { hypoglycaemia]; further fluid administration ( } 0.9 \% \text { sodium chloride) guided by individual needs as assessed clinically } \\
\text { or by central venous pressure and avoiding overload. } \\
\text { The quantity infused depends on evolution of blood-pressure, heart rate, diuresis, ionogram, central venous pressure } \\
\text { and pulmonary auscultation }\end{array}$ \\
\hline & $\rightarrow$ Depending on the severity of the crisis and on the intercurrent illness [e.g. low-dose heparin; antibiotic treatment] \\
\hline
\end{tabular}


Adrenal Suppression and Exogenous Cushing Syndrome After Inhaled and Topical Corticosteroids

Table 8. Cushing syndrome - comparation between endogenous and exogenous types

\begin{tabular}{|l|l|}
\hline \multicolumn{1}{|c|}{ Exclusively in exogenous Cushing } & \multicolumn{1}{c|}{ More frequent in endogenous Cushing } \\
\hline Intracranial hypertension & Arterial hypertension \\
\hline Glaucoma; cataract & Acne and hirsutism \\
\hline Aseptic bone necrosis & Menstrual abnormalities \\
\hline Pancreatitis & Striae and ecchymosis \\
\hline Panniculitis & Plethoric facies \\
\hline \multicolumn{2}{|c|}{ In both endogenous and exogenous Cushing } \\
\hline Central obesity and fat redistribution. Peripheral myopathy and cardiomyopathy \\
\hline Osteoporosis. Atherosclerosis and thrombosis. Peptic ulceration and digestive bleeding \\
\hline Glucose intolerance and diabetes mellitus. Natrium retention and potassium excretion \\
\hline Psychological changes - lability, insomnia, psychosis, cerebral atrophy \\
\hline Delayed healing. Immunosuppression and lymphopenia; undercurrent infections \\
\hline Diminution of height growth in children \\
\hline
\end{tabular}

Table 9. Treatment of GIO in adults ${ }^{27,28}$

\begin{tabular}{|c|c|}
\hline FRAX GC-adjusted ${ }^{*}$ & ATTITUDE \\
\hline \multicolumn{2}{|c|}{ CATEGORY - Adults $\geq 40$ years of age, with GC therapy for $\geq 3$ months } \\
\hline $\begin{array}{l}\text { Low fracture risk - FRAX } 10 \text {-year risk of } \\
\text { major osteoporotic fracture }{ }^{\star *}<10 \% \text { and risk } \\
\text { of hip fracture } \leq 1 \%\end{array}$ & $\begin{array}{l}\text { Prefer optimize calcium intake }(0.8-1 \mathrm{~g} / \text { day) and vitamin D intake }(600-800 \mathrm{IU} / \text { day) and } \\
\text { lifestyle modifications (balanced diet, smoking cessation, regular weight-bearing or resis- } \\
\text { tance training exercise, limiting alcohol to } 1-2 \text { alcoholic beverages/day) over treatment with } \\
\text { bisphosphonates, teriparatide, denosumab, raloxifene. }\end{array}$ \\
\hline $\begin{array}{l}\text { Moderate fracture risk - FRAX 10-year risk } \\
\text { of major osteoporotic fracture 10-19\% or risk } \\
\text { of hip fracture } 1-3 \%\end{array}$ & $\begin{array}{l}\text { ORAL BISPHOSPHONATE. Based on cost-effectiveness criteria alendronate and risedronate } \\
\text { are preferred. Prefer an oral bis-phosphonate over IV bisphosphonates, teriparatide, denosu- } \\
\text { mab. If oral bisphosphonates are not appropriate, in order: (1) intravenous (IV) bisphospho- } \\
\text { nates - acid zoledronic; (2) teriparatide }{ }^{* \star *} ; \text {; (3) denosumab (4) raloxifene. }\end{array}$ \\
\hline $\begin{array}{l}\text { High fracture risk: Very high-dose GC }{ }^{\star \star * *} \text { OR } \\
\text { FRAX risk of major osteoporotic fracture } \\
\geq 20 \% \text { or risk of hip fracture } \geq 3 \% \text { OR prior } \\
\text { osteoporotic fracture OR hip/spine bone } \\
\text { mineral density (BMD) T score } \leq-2.5 \text { in men } \\
\text { age } \geq 50 \text { years or post-menopausal women. }\end{array}$ & $\begin{array}{l}\text { ORAL BISPHOSPHONATE. Treat with an oral bisphosphonate over IV bisphosphonates, } \\
\text { teriparatide, denosumab, or raloxifene. } \\
\text { If oral bisphosphonates are not appropriate, in order: (1) IV bisphosphonates [higher risk } \\
\text { profile for IV]; (2) Teriparatide [cost and burden of injections]; (3) Denosumab [lack of safety } \\
\text { data in people treated with immunosuppressive agents]; (4) Raloxifene, for postmenopausal } \\
\text { women [lack of adequate data on benefits (impact on risk of vertebral and hip fractures in GC } \\
\text { users) and potential harms (clotting risks, mortality)]. }\end{array}$ \\
\hline \multicolumn{2}{|l|}{ SPECIAL CASES IN THIS CATEGORY } \\
\hline \multicolumn{2}{|c|}{$\begin{array}{l}\text { Adults age } \geq \mathbf{4 0} \text { years continuing } \mathbf{~ G C} \text { treatment who have had a fracture that occurred after } \mathbf{2} \mathbf{1 8} \text { months of treatment with an oral bispho- } \\
\text { sphonate or who have had a significant loss of } \mathrm{BMD}(\geq 10 \% / \text { year) } \rightarrow \text { Treat with another class of OP medication (teriparatide or denosumab; } \\
\text { or, consider IV bisphosphonate). }\end{array}$} \\
\hline \multicolumn{2}{|c|}{$\begin{array}{l}\text { Adults age } \geq \mathbf{4 0} \text { years who have completed } \mathbf{5} \text { years of oral bisphosphonate treatment and who continue } \mathbf{G C} \text { treatment and are assessed to } \\
\text { be at moderate-to-high risk of fracture } \rightarrow \text { Continue active treatment, with an oral bisphosphonate beyond } 5 \text { years or switch to IV bispho- } \\
\text { sphonate. }\end{array}$} \\
\hline \multicolumn{2}{|c|}{ CATEGORY - Adults $<40$ years of age, with GC therapy for $\geq 3$ months } \\
\hline $\begin{array}{l}\text { Low risk = None of above risk factors other } \\
\text { than GC }\end{array}$ & $\begin{array}{l}\text { Optimize calcium and vitamin } \mathbf{D} \text { intake and lifestyle modifications over treatment with } \\
\text { bisphosphonates, teriparatide, or denosumab. }\end{array}$ \\
\hline $\begin{array}{l}\text { Moderate fracture risk }=\text { Hip or spine BMD Z } \\
\text { score }<-3 \text { OR rapid bone loss }(\geq 10 \% \text { at the } \\
\text { hip or spine over } 1 \text { year })+ \text { continuing GC at } \\
\geq 7.5 \text { mg prednisone/day for } \geq 6 \text { months }\end{array}$ & \multirow{2}{*}{$\begin{array}{l}\text { TREAT WITH AN ORAL BISPHOSPHONATE over calcium and vitamin D alone. Oral bispho- } \\
\text { sphonate over intravenous (IV) bisphosphonates, teriparatide, or denosumab [oral bispho- } \\
\text { sphonates preferred for safety, cost, and because of lack of evidence of superior antifracture } \\
\text { benefits from other medications]. } \\
\text { If oral bisphosphonates are not appropriate, in order of preference: (1) IV bisphosphonates; } \\
\text { (2) Teriparatide; (3) Denosumab. } \\
\text { Estimate the need for sexual hormones therapy in premenopausal women with amenorrhea } \\
\text { and in men with hypogonadism. }\end{array}$} \\
\hline $\begin{array}{l}\text { High fracture risk = Prior osteoporotic } \\
\text { fracture(s) }\end{array}$ & \\
\hline \multicolumn{2}{|c|}{$\begin{array}{l}\text { - FRAX-GC = FRAX-glucocorticoid adjusted risk - increase the risk generated with FRAX - by } 1.15 \text { for major osteoporotic fracture and } 1.2 \text { for hip fracture if GC treatment is equivalent }>7.5 \\
\text { mg prednisone/day. } \\
\text { " Major osteoporotic fracture includes fractures of the spine, hip, wrist, or humerus. } \\
\cdots-\text { Teriparatide is recommended for the failure of bisphosphonate therapy }=\text { the occurrence of extra-vertebral fractures or } \geq 2 \text { vertebral fractures after } 12 \text { months of bisphosphonate therapy. } \\
\cdots\end{array}$} \\
\hline
\end{tabular}


rapid bone mass, $12 \%$ in the first 3-12 months followed by a phase of slower bone mass loss, of $2-15 \%$ every 12 months. GIO can occur not only after systemic CS, but with $\mathrm{ICS}^{23}$ and topical $\mathrm{GC}^{24}$. One short guide for prevention and treatment of GIO is presented Table 9.

\section{CONCLUSION}

It is estimated that approximately $6 \%$ of hospitalized patients have $\mathrm{GC}$-induced tertiary $\mathrm{AI}^{25}$. In this article, we intended to draw attention to the endocrine effects generated by compartmental GC treatments. GC preparations with the so-called local effects (e.g. topical, inhaled, intra-articular) have been shown to exert systemic effects that can not be neglected, the most important for endocrinologists being exogenous Cushing syndrome and glucocorticoid-induced AI. One meta-analysis showed evidence of AI following low doses and short durations of GC ( $<5 \mathrm{mg}$ prednisolone

\section{References}

1. Decani S, et al. latrogenic Cushing's syndrome and topical steroid therapy: Case series and review of the literature. J. Dermatol. Treat. 2014, 25, 495-500.

2. Fischli S, et al. Dehydroepiandrosterone Sulfate in the Assessment of the Hypothalamic-Pituitary-Adrenal Axis. J Clin Endocrinol Metab 2008; 93: 539-542.

3. Beishuizen A, et al. Decreased levels of dehydroepiandrosterone sulphate in severe critical illness: a sign of exhausted adrenal reserve? Critical Care 2002; 6:434.

4. Dow A, Yu R, Carmichael J. Too little or too much corticosteroid? Coexisting adrenal insufficiency and Cushing's syndrome from chronic, intermittent use of intranasal betamethasone. Endocrinology, Diabetes \& Metabolism Case Reports 10 2013, EDM130036.

5. Hengge UR, et al. Adverse effects of topical glucocorticosteroids. J Am Acad Dermatol 2006;54:1-15.

6. National Heart, Blood, and Lung Institute Expert Panel Report 3 (EPR 3): Guidelines for the Diagnosis and Management of Asthma; 2007 \& Global Initiative for Asthma (GINA) Management and Prevention; 2014

7. Daley-Yates PT. Inhaled corticosteroids potency and therapeutic index. Br J Clin Pharmacol 2015:80:3:372-380.

8. Toogood JH, et al. Bioequivalent doses of budesonide and prednisone in moderate and severe asthma. J Allergy Clin Immunol 1989;84:688-700

9. Kowalski ML, et al. Adrenal suppression by inhaled corticosteroids in patients with asthma: A systematic review and quantitative analysis. Allergy Asthma Proc. 2016, 37, 9-17.

10. Dahl R. Systemic side effects of inhaled corticosteroids in patients with asthma. Respiratory Medicine 2006; 100: 1307-1317

11. Todd GR, et al. Survey of adrenal crisis associated with inhaled corticosteroids in the United Kingdom. Arch Dis Child 2002;87:457-61.

12. Guaraldi $F$, et al. Secondary adrenal insufficiency: Where is it hidden and what does it look like? Front. Horm. Res. 2016, 46, 159-170.

13. Mortimer KJ, et al. Oral and inhaled corticosteroids and adrenal insufficiency: a case-control study. Thorax. 2006 May;61(5): 405-8.

14. Baek JH, et al. Recovery of Adrenal Function in Patients with Glucocorticoids Induced Secondary Adrenal Insufficiency. Endocrinol Metab 2016; 31:153-160. equivalent dose/day, $<4$ weeks of exposure, cumulative dose $<0.5 \mathrm{~g}$, and following tapered withdrawal ${ }^{26}$. There is no clinical guidance for AI occurring after systemic $\mathrm{CS}$ and even lesser agreements for AI induced by local GC. This data must lead the practitioners using topical, inhaled, or intra-articular GC to an increased alertness level toward the possibility that even compartmental administration could cause significant systemic endocrine effects.

\section{Compliance with ethics requirements:}

The authors declare no conflict of interest regarding this article.

The authors declare that all the procedures and experiments of this study respect the ethical standards in the Helsinki Declaration of 1975, as revised in 2008(5), as well as the national law. Informed consent was obtained from all the patients included in the study.

15. Woods $\mathrm{CP}$, et al. Adrenal suppression in patients taking inhaled glucocorticoids is highly prevalent and management can be guided by morning cortisol. European Journal of Endocrinology 2015; 173: 633-642.

16. Broersen et al. Adrenal Insufficiency in Corticosteroids Use. J Clin Endocrinol Metab 2015; 100: 2171-2180.

17. Leong SH, Shander S, Ratnasingam J. Predicting Recovery of The Hypothalamic-Pituitary-Adrenal Axis After Prolonged Glucocorticoid Use. Endocr Pract. 2018 Jan; 24(1):14-20.

18. Paragliola RM, Corsello SM. Secondary adrenal insufficiency: from the physiopathology to the possible role of modified-release hydrocortisone treatment. Minerva Endocrinol. 2017.

19. Bondugulapati LNR, Rees DA. Recommendations for management of ICS-induced hypothalamic-pituitary-adrenal axis suppression. Clin Endocrinol. 2016; 85(2):165-169.

20. Smans LC, et al. Incidence of adrenal crisis in patients with adrenal insufficiency. Clin. Endocrinol. Oxf. 2016, 84, 17-22.

21. Allolio B. Adrenal Crisis. European Journal of Endocrinology 2015; 172, R115-R124.

22. Jackson DJ, et al. Quintupling Inhaled Glucocorticoids to Prevent Childhood Asthma Exacerbations. N Engl J Med, March 3 2018; DOI: 10.1056/NEJMoa1710988.

23. Singh S and Loke YK. An overview of the benefits and drawbacks of inhaled corticosteroids in chronic obstructive pulmonary disease. Int J Chron Obstruct Pulmon Dis 2010; 5:189-195.

24. Millard TP, et al. Bone mineral density of patients with chronic plaque psoriasis. Clin Exp Dermatol. 2001;26:446-8.

25. Paragliola RM, et al. Treatment with Synthetic Glucocorticoids and the Hypothalamus-Pituitary-Adrenal Axis. Int. J. Mol. Sci. 2017, 18, 2201.

26. Joseph RM, et al. Systemic glucocorticoid therapy and adrenal insufficiency in adults: A systematic review. Seminars in Arthritis and Rheumatism 2016; 46: 133-141.

27. Buckely L, et al. 2017 ACR Guideline for the Prevention and Treatment of Glucocorticoid-Induced Osteoporosis. Arthritis Rheumatol 2017 Aug; 69(8):1521-1537.

28. Compston J, et al. UK clinical guideline for the prevention and treatment of osteoporosis. Arch Osteoporos 2017; 12:43, 1-24. 